\title{
Nutrient Composition and Consumer Acceptability of Cultivated Edible Mushrooms
}

\author{
Ann Mary Roy* and Betty Rani Isaac \\ Department of Home Science, St. Teresa's College, Ernakulam - 682011, Kerala, India; \\ annmarryroyngc@gmail.com
}

\begin{abstract}
Worldwide mushrooms have gained great commercial interest due to their nutraceutical and nutritional properties, even though lots of new food products being introduced in the market day by day. Mushroom cultivation and utilization is not catching up in India. The present study was undertaken with the following objectives to have an insight on the consumer preference for mushrooms, to conduct a market survey on availability and cost of cultivated mushrooms analyze the proximate nutrient composition of the selected mushroom sand. Hundred home makers in Ernakulum city were selected to study the consumer preference for mushrooms. Survey conducted showed that majority (78\%) of them did not purchase mushroom. About one- fourth (22\%) of urban consumers bought mushrooms [white button mushroom (Agaricus), oyster mushroom (Pleurotus) and milky mushrooms (Calocybe)]. Market survey revealed that only three mushroom species namely, Agaricus bisporus, Pleurotuso streatus and Calocybe indica were available in Ernakulam market. Proximate analysis of these three varieties of mushrooms showed that mushrooms are rich in protein (15.4 g to $21.3 \mathrm{~g}$ ) and fiber (8.3 g to 19.8 g) but low in fat content ( $2.9 \mathrm{~g}$ to $4.7 \mathrm{~g}$ ) per $100 \mathrm{gms}$.
\end{abstract}

\section{Introduction}

Shortage of food and diminishing quality of human health will be growing concerns because of the population increase and urbanization, with a concomitant reduction in cultivable land. Converting lignocellulosic agricultural and forest residues into protein-rich mushrooms is one of the most economically viable and sustainable biotechnology processes to address world food demand, especially protein demand 1 . Mushrooms because of its enticing flavor, taste and ample nutrition are gaining popularity and has scope to alleviate malnutrition.

Though India is not a major producer of mushrooms but has potential to cultivate them in the future. It is a good source of lysine and can complement to cereal based Indian diet. Further it possesses many medicinal attributes. Despite this fact mushroom cultivation and its utilization is not catching up fast. Mushrooms are an important commodity worldwide. Cultivated mushrooms now become popular all over the world.
The consumption of mushrooms can make a valuable addition to the often unbalanced diets of people in developing countries Marshall and Nair². However, a thorough understanding of consumption trends is not yet available. In India especially in Kerala State, the nutrient composition of edible cultivated mushrooms and consumer preferences and perceptions has not been studied. It is in this background the present study "Nutrient composition and consumer acceptability of cultivated edible mushrooms" becomes immensely relevant, because mushrooms with its huge health benefits can solve many health problems and problems related to malnutrition.

\section{Materials and Methods}

The methodology of the present study "Nutrient composition and consumer acceptability of cultivated edible mushrooms" was discussed under three different phases -

${ }^{*}$ Author for correspondence 
Phase 1. Consumer survey to Study the Mushroom Consumption Pattern

\subsection{Selection of Area}

The area selected for the study was Ernakulam city, Kerala.

\subsection{Selection of Subjects}

The study population selected for the study comprised of home makers of hundred families. The study population was selected using convenience sampling.

\subsection{Selection of Tool}

The method used to collect data in the present study was house hold survey. Information regarding consumer acceptance of mushrooms were collected using a combination of open-ended and closed ended questionnaires.

\section{Phase 2. Market Survey to Study the Availability of Mushrooms}

\subsection{Selection of Area}

Markets in Ernakulam, Kerala were selected for the study.

\subsection{Selection of Tool}

Market survey was done using observation technique and questionnaire. Questionnaire consisted of questions including general observations, type of mushroom and cost, purchase, availability, demand, storage, income, packaging etc.

\subsection{Conduct of Study and Data Collection}

A total of 10 shops representing local, super and hyper markets were purposefully selected to study the market availability of mushrooms.

\section{Phase 3. Nutrient Analyses}

\subsection{Collection of Sample}

Based on the data obtained from market survey three types of mushrooms were selected for nutrient analysis. Fresh mushrooms sample was purchased from local market for in-depth study. The mushrooms purchased are,
- Button mushroom (Agaricus bisporus),

- Milky mushroom (Pleurotuso streatus),

- Oyster mushroom (Calocybe indica).

\subsection{Preparation of Sample}

\subsubsection{Raw Sample Analysis}

Raw samples were analyzed to obtain moisture and vitamin $\mathrm{C}$ content of the mushrooms. The non-edible portions and unwanted wastes or particles (e.g. soil, portion of compost where they were grown, spoiled portion of mushrooms, etc.) if remained were separated and removed. Then total weight of edible fresh mushrooms was recorded.

\subsubsection{Dried Sample Analysis}

The mushrooms were air-dried at $100{ }^{\circ} \mathrm{C}$ and stored in airtight containers to prevent absorption of moisture. Each specimen was carefully labeled. This method was adopted to conduct proximate analysis and mineral analysis of mushrooms.

\subsection{Determination of Nutritive Value}

For determination of nutritive value, the following nutrients were estimated using the procedure given below.

Moisture analysis was done using standard procedure and the moisture content was calculated using the following equation:

Moisture $(\%)=($ initial weight - final weight $) \times 100 /$ weight of sample ${ }^{3}$. Crude protein was determined by micro Kjeldahl method described by Pearson ${ }^{4}$. Crude fat content of the samples was determined by extracting a known weight of powdered mushroom sample with petroleum ether, using Soxhlet apparatus. Crude fibre was determined and calculated as below.

Crude fiber $(\mathrm{g} / 100 \mathrm{~g}$ sample $)=[100-($ moisture + fat)] $\times($ We-Wa $) /$ Wt of sample ${ }^{3}$.

The content of the available carbohydrate was determined by the following equation:

Carbohydrate $(\mathrm{g} / 100 \mathrm{~g}$ sample $)=100-[($ moisture + fat + protein + ash + crude fiber) g/100 g] $]^{3}$. Energy was determined by following the method described by Pearson, (1976). Total energy is estimated using the following equation:

Energy $(\mathrm{Kcal} / 100 \mathrm{~g})=\left(\right.$ carbohydrate $\left.{ }^{\star} 4\right)+($ protein $\left.{ }^{\star} 4\right)+\left(\right.$ total fat $\left.{ }^{*} 9\right)$. 
Then total ash was calculated as:

Ash content $(\mathrm{g} / 100 \mathrm{~g}$ sample $)=$ weight of ash $\times$ 100/weight of sample taken ${ }^{3}$. Sodium and potassium content of the sample was determined using flame photometer.

Iron and phosphorous was determined calorimetrically. Calcium and vitamin $\mathrm{C}$ present in the sample was determined by titration.

\subsection{Data Interpretation and Analysis}

Questionnaire responses were collected and descriptive analysis of the data was done and the results were discussed.

\section{Results and Discussion}

\subsection{Consumer Acceptability of Mushrooms}

A consumer survey was conducted among 100 home makers in Ernakulam district, the commercial capital of Kerala, to study the acceptability of mushroom and the results thus obtained are given below:

Majority of the subjects (43\%) belonged to the age group of 45 to 50 years. Educational qualification of the subjects showed that $47 \%$ of them had completed degree or diploma, $34 \%$ of the subjects acquired their higher secondary education, $15 \%$ were post graduates and remaining $4 \%$ had completed their professional courses (Table 1). 69\% of them were housewives, $27 \%$ were employed and remaining $4 \%$ were doing business.

Majority (50.6\%) responded that they were not interested in using mushroom. This was mainly because

Table 1. Personal details of the subjects $(\mathrm{N}=100)$

\begin{tabular}{|l|c|}
\hline Age of the respondent (years) & Percentage \\
\hline Below 40 & 10.0 \\
\hline 40 to 44 & 33.0 \\
\hline 45 to 50 & 43.0 \\
\hline 51 to 56 & 12.0 \\
\hline Above 56 & 2.0 \\
\hline Educational qualification & 34.0 \\
\hline Up to higher secondary & 47.0 \\
\hline Degree/diploma & 15.0 \\
\hline Post graduation & 4.0 \\
\hline Professional degrees & \multicolumn{2}{|l|}{} \\
\hline
\end{tabular}

of their lack of familiarity with the usage of mushrooms. Around $20 \%$ of the subject responded that they were not purchasing mushroom because it was expensive and $19.2 \%$ of the subject did not buy it as they have no knowledge regarding the health benefits and uses of mushroom. Some of the respondents (10\%) had a fear that consumption of mushroom may lead to health problems such as allergy, abdominal discomfort and vomiting.

Reason for preferring mushroom studied among the mushroom users $(22 \%)$ revealed that, all the subjects liked the taste of mushroom. $50 \%$ of the mushroom users reported that price of mushroom was pocket friendly whereas; another half reported that mushrooms are costly. Majority of the subjects (81\%) reported that preparation process such as cleaning, cutting and preparations were easy and $18.2 \%$ reported that the preparative process were not so easy.

\subsection{Market Survey on Mushroom Availability}

To study the market availability of mushrooms, a market survey was conducted at ten shops selling mushroom in the Ernakulam district. To the results thus obtained are given below.

Table 2, shows the type of shops selected for survey, majority of the shops (60\%) selected were grocery shops and the remaining $40 \%$ were supermarkets. No exclusive shops of mushrooms were found in the selected locale.

Market survey revealed that only three types of mushrooms were available at shops in Ernakulam, namely, button mushroom, oyster mushroom and milky mushroom. $50 \%$ of the shops sold all the three types of mushroom namely, button, oyster and milky mushroom

Table 2. Types of shop selected for the study $(\mathrm{N}=10)$

\begin{tabular}{|l|c|c|}
\hline Type of shop & Number & Percentage (\%) \\
\hline Grocery shops & 6 & 60.0 \\
\hline Supermarkets & 4 & 40.0 \\
\hline Exclusive shops & 0 & 0.0 \\
\hline
\end{tabular}

Table 3. Types of mushroom sold $(\mathrm{N}=10)$

\begin{tabular}{|l|c|c|}
\hline Type of mushroom & Number & Percentage (\%) \\
\hline Button mushroom & 3 & 30.0 \\
\hline Oyster mushroom & 1 & 10.0 \\
\hline Milky mushroom & 1 & 10.0 \\
\hline All the above three varieties & 5 & 50.0 \\
\hline
\end{tabular}


Table 4. Proximate composition of mushrooms

\begin{tabular}{|l|c|c|c|}
\hline \multirow{2}{*}{ Nutrients } & \multicolumn{2}{|c|}{ Type of mushrooms } \\
\cline { 2 - 4 } & Agaricus bisporus & Pleurotus ostreatus & Calocybe indica \\
\hline Moisture(g/100 g fresh) & 91 & 91 & 15.4 \\
\hline Protein $(\mathrm{g} / 100 \mathrm{~g}$ dried) & 18.4 & 21.3 & 3.1 \\
\hline Fat $(\mathrm{g} / 100 \mathrm{~g}$ dried) & 4.7 & 2.9 & 8.3 \\
\hline Crude fiber $(\mathrm{g} / 100 \mathrm{~g}$ dried) & 13.8 & 19.8 & 67.8 \\
\hline Carbohydrate $(\mathrm{g} / 100 \mathrm{~g}$ dried) & 53.1 & 48 & 360 \\
\hline Energy $($ Kcal/100 g dried) & 328 & 303 & 5.5 \\
\hline Ash $(\mathrm{mg} / 100 \mathrm{~g}$ dried) & 10.1 & 7.9 & 198 \\
\hline Sodium $(\mathrm{mg} / 100 \mathrm{~g}$ dried) & 328 & 264 & 5 \\
\hline Potassium $(\mathrm{mg} / 100 \mathrm{~g}$ dried) & 13.2 & 7.6 & 17 \\
\hline Iron $(\mathrm{mg} / 100 \mathrm{~g}$ dried) & 17 & 30 & 140 \\
\hline Phosphorous $(\mathrm{mg} / 100 \mathrm{~g}$ dried) & 80 & 35.7 & 19.5 \\
\hline Calcium $(\mathrm{mg} / 100 \mathrm{~g}$ dried) & 12.3 & 25.9 & 31.2 \\
\hline Vitamin C $(\mathrm{mg} / 100 \mathrm{~g}$ dried) & 15.7 & & \\
\hline
\end{tabular}

and $30 \%$ were selling button mushroom and an equal percentage of 10 were selling oyster and milky mushroom only (Table 3).

All the three varieties of mushrooms consisted of $91 \%$ of moisture.

Hundred grams of dried Agaricus bisporus contained $18.4 \mathrm{~g}$ of protein, $4.7 \mathrm{~g}$ of fat, $13.8 \mathrm{~g}$ of fibre, $53.1 \mathrm{~g}$ of carbohydrate, $328 \mathrm{Kcal}$ of energy, $10.1 \%$ of ash, $328 \mathrm{mg}$ of potassium, $17 \mathrm{mg}$ of iron, $80 \mathrm{mg}$ of phosphorous, $13.2 \mathrm{mg}$ of sodium $12.3 \mathrm{mg}$ of calcium and $15.7 \mathrm{mg}$ of vitamin C.

Hundred grams of dried Pleurotus ostreatus contained $21.3 \mathrm{~g}$ of protein, $2.9 \mathrm{~g}$ of fat, $19.8 \mathrm{~g}$ of fibre, $48 \mathrm{~g}$ of carbohydrate, $303 \mathrm{Kcal}$ of energy, $7.9 \%$ of ash, $264 \mathrm{mg}$ of potassium, $7.6 \mathrm{mg}$ of sodium, $30 \mathrm{mg}$ of iron, $160 \mathrm{mg}$ of phosphorous, $35.7 \mathrm{mg}$ of calcium and $25.9 \mathrm{mg}$ of vitamin C.

Hundred grams of dried Calocybe indica contained $15.4 \mathrm{~g}$ of protein, $3.1 \mathrm{~g}$ of fat, $8.3 \mathrm{~g}$ of fibre, $67.8 \mathrm{of}$ carbohydrate, $360 \mathrm{Kcal}$ of energy, $5.5 \%$ of ash, $198 \mathrm{mg}$ of potassium, $5 \mathrm{mg}$ of sodium, $17 \mathrm{mg}$ of iron, $140 \mathrm{mg}$ of phosphorous, $19.5 \mathrm{mg}$ of calcium and $31.2 \mathrm{mg}$ of vitamin C (Table 4).

\section{Summary and Conclusion}

Consumer preference for mushroom was found to be low as only $22 \%$ of the selected subjects used cultivated mushrooms. Only three varieties of mushrooms were available in shops of Ernakulam city. The data obtained from the present study showed that dietary mushrooms analyzed are good source of nutrients specially protein and fiber. Being rich in protein mushrooms can overcome the problems of protein deficiency, world's most serious human nutritional problem. The dietary fibre plays an important role in decreasing the risks of many disorders such a constipation, diabetes, cardiovascular diseases, obesity etc. Ernakulam leads Kerala with largest number of diabetic subjects earning the dubious distinction of being termed the 'diabetes capital of Kerala'. Mushroom with its high fibre content if properly being used, can help to control the incidence of diabetes. Provision of well stored quality mushrooms in markets will definitely increase the purchase of mushroom among the consumers. For promotion of mushroom cultivation, regular training programmes can be conducted. Training kits comprising of spawn, polythene covers and booklet for starters can also being supplied to improve production of mushroom at household level itself. Intake of mushroom can be increased by the development of value added products such as mushroom powders, dried mushroom, mushroom soup, mushroom curry etc.

\section{References}

1. Hawksworth DL. The fungal dimension of biodiversity: Magnitude, significance and conservation. Mycological Research. 1991; 95:641-55. https://doi. org/10.1016/S0953-7562(09)80810-1 
2. Marshall E, Nair NG. Make money by growing mushrooms. Diversification Booklet Number- 7, 3. 2009.

3. Raghuramulu N, Madhavan NK, Kalyanasundaram SA. Manual of laboratory techniques. Hyderabad,
India: National Institute of Nutrition. Indian Council of Medical Research. 2003. sp. 56-70.

4. Pearson D. Chemical analysis of foods. $7^{\text {th }}$ ed. London: J and A Churchill; 1976. p. 34-56. 